\title{
The Effects of Endothelial Protein C Receptor Gene Polymorphisms on the Plasma sEPCR Level in Venous Thrombosis Patients
}

\section{Endotelyal Protein C Reseptör Geni Polimorfizmlerinin Venöz Trombozlu Olgularda sEPCR Üzerindeki Etkisi}

\author{
Afife Karabıyık , Erkan Yılmaz², Yonca Eğin², Nejat Akar² \\ ${ }^{1}$ Ankara University, Biotechnology Institute, Ankara, Turkey \\ ${ }^{2}$ Ankara University, Department of Pediatric Molecular Genetics, Ankara, Turkey
}

\begin{abstract}
Objective: The aim of this study was to investigate variations in the endothelial cell protein $C$ receptor gene (EPCR gene) that may play a role in thrombosis and the effects of these variations on the plasma soluble endothelial cell protein $C$ receptor (sEPCR) level in Turkish patients with venous thrombosis.
\end{abstract}

Material and Methods: This study included 111 thrombosis patients and 73 healthy controls. Following DNA extraction, PCR, SSCP, and DNA sequencing analysis of 4 exons of the EPCR gene was performed. Plasma SEPCR was measured via enzyme-linked immunosorbent assay (ELISA).

Results: In all, 3 polymorphisms were detected in exons 1-4. C3998T (SNP no: rs2069952) polymorphism was detected in intron 2 and C4678G (A1 haplotype) (SNP no: rs9574) in the 3' untranslated region (3'UTR). There weren't any significant differences in $\mathrm{C} 3998 \mathrm{~T}$ polymorphism between the control and patient groups. There wasn't a significant difference in plasma sEPCR levels between both controls and patients that carried the A1 allele. A4600G substitution (A3 haplotype) (SNP no: rs867186) was observed in exon 4 and was associated with a 2.04-fold higher risk of thrombosis. A3 allele carriers had higher SEPCR levels than those without the allele. Mean sEPCR level in the patients with the homozygous $\mathrm{A} 3$ allele was $289 \mathrm{ng} \mu \mathrm{L}^{-1}$, versus $113.42 \mathrm{ng} \mu \mathrm{L}-1$ in those with the homozygous $\mathrm{Al}$ allele.

Conclusion: The Al haplotype might offer protection against thrombosis and the A3 haplotype might be associated both with elevated plasma SEPCR and elevated risk of venous thrombosis in the Turkish population. Plasma sEPCR levels were significantly higher in those that carried the $\mathrm{A} 3$ allele $(4600 \mathrm{~A}>\mathrm{G})$ (both patients and controls). Among the participants that carried the A1 allele $(4678 C>$ G), plasma SEPCR did not differ significantly.

Key Words: Thrombosis, Endothelial protein C receptor (EPCR), Soluble EPCR (sEPCR), EPCR haplotypes

Özet

Amaç: Bu çalışmada, trombozda önemli bir role sahip olan EPCR genindeki varyasyonların tespit edilmesi ve bu varyasyonların Türk populasyonunda plazma SEPCR seviyeleri üzerindeki olası etkisinin incelemesi amaçlanmıştır.

Gereç ve Yöntemler: Çalışmamız 111 trombozlu olgu ve 73 sağlıklı kontrol içermektedir. EPCR geninin dört ekzonu

Address for Correspondence: Afife KARABIYIK, M.D.,

Ankara Üniversitesi, Tıp Fakültesi, Pediatrik Moleküler Genetik Laboratuvarı, 06190 Cebeci, Ankara, Turkey

Phone: +90 31259563 48/115 E-mail: afifekrbyk@gmail.com 
intronlardan başlanan primerler kullanılarak PCR, SSCP ve DNA Dizi Analizi ile taranmıştır. Plazma sEPCR düzeyleri ELISA yöntemi kullanılarak ölçülmüştür.

Bulgular: Bu çalışmada, EPCR haplotipleri ile sEPCR seviyesi arasındaki ilişki incelenmiş ve EPCR geninin taranan dört ekzonunda üç farklı polimorfizm saptanmıştır. Bunlardan C3998T (rs2069952) genin 2. intronunda, A1 haplotipini oluşturan C4678G (rs9574) ise EPCR geninin 3' UTR bölgesinde tespit edilmiştir. EPCR geninde tespit edilen diğer bir polimorfizm ise A3 haplotipini oluşturan ve ekzon 4'de yer alan A4600G (rs867186) değişimidir. A3 allelini homozigot olarak taşıyan hastalarda ortalama SEPCR seviyesi $289 \mathrm{ng} / \mu \mathrm{l}$ iken, A1 allelini homozigot olarak taşıyanlarda 113,42 ng/ul'dur.

Sonuç: İstatistik analizler kontrol ve hastalar arasında C3998T değişiminin tromboz riski açısından anlamlı olmadığını göstermiştir. Al haplotipinin ise trombozdan koruyucu bir etkiye sahip olabileceği saptanmış ancak Al $(4678 C>G)$ allelini taşıyan bireylerde sEPCR seviyesinde de anlamlı bir değişiklik saptanamamıştır. Buna karşılık A3 haplotipinin tromboz için 2.04 kat risk getirdiği ve $A 3(4600 A>G)$ alleli taşıyanların taşımayanlara göre daha yüksek sEPCR seviyesine sahip olduğu saptanmıştır. A3 haplotipi Türk populasyonunda hem trombotik riskle hem de artan sEPCR seviyesiyle ilişkilendirilebilir.

Anahtar Sözcükler: Tromboz, Endotelyal protein C reseptörü (EPCR), Solubl EPCR (sEPCR), EPCR haplotipleri

\section{Introduction}

The protein $\mathrm{C}(\mathrm{PC})$ anticoagulant pathway is physiologically important to the regulation of coagulation. While the PC pathway plays a crucial role in controlling thrombosis, it also has anti-inflammatory functions [1-3]. The essential components of this pathway include thrombin, thrombomodulin (TM), endothelial cell PC receptor (EPCR), PC, protein S, and protease-activated receptor 1 (PAR-1).

The PC pathway is a natural anticoagulation mechanism that prevents excessive thrombin generation. When Thrombin binds to TM, PC is activated about 1000 times faster than free thrombin [1]. The thrombin-TM complex activates PC. Activated PC (APC) requires protein $\mathrm{S}$ as a cofactor. APC limits amplification and progression of the coagulation cascade via proteolytic inactivation of factor $\mathrm{Va}$ (FVa) and factor FVIIIa [2]. PC activation increases approximately 20-fold in vivo when it is bound to EPCR [3].

EPCR binds to PC and also APC with high affinity and promotes PC activation on endothelium by increas- ing the catalytic efficiency of the thrombin-TM complex [4-6]. Although EPCR is an endothelial cell-specific type I transmembrane protein, a soluble form of this receptor circulates in plasma [7-9]. EPCR is similar to molecules of the class I major histocompatibility complex, in particular the CD1-subfamily [10]. In addition to the extracellular domains, EPCR has a transmembrane domain and a very short cytoplasmic tail.

Primary defects of the PC pathway increase the risk of venous thrombosis [10]. A metalloprotease cleaves the entire extracellular domain of EPCR from the cell membrane [11]. This cleavage results in the formation of soluble EPCR (sEPCR). sEPCR can bind both to PC and APC with an affinity similar to that of intact membrane-bound EPCR. sEPCR inhibits PC activation by competing with the membrane form of EPCR on vessel walls [9]. sEPCR also inhibits inactivation of factor Va and APC anticoagulant activity by blocking the interaction of APC and negatively charged membrane surfaces [12].

Plasma sEPCR is elevated in patients with systemic inflammatory diseases [13]. sEPCR binding to APC blocks

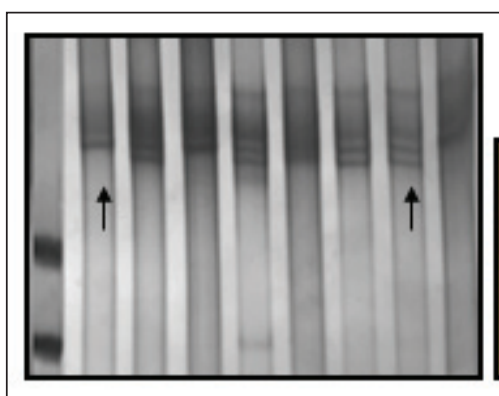

Exon 3

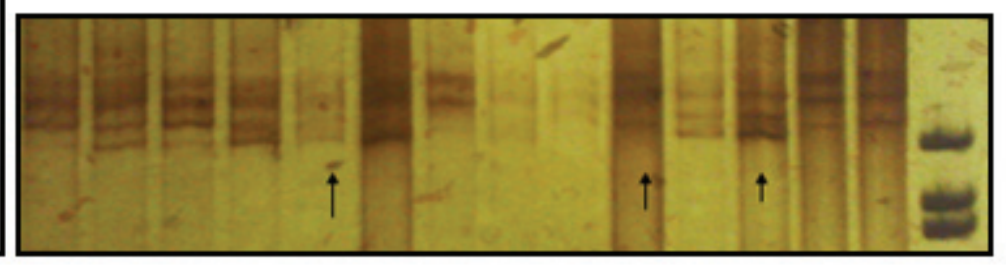

Exon 4
Figure 1: SSCP shows band pattern variation in exon 3 and the first region of exon 4. 
phospholipid interaction and alters the active site of APC. Inherited defects of the PC pathway are associated with an increased tendency for venous thromboembolism (VTE) [14], whereas low plasma sEPCR (sEPCR<30 ng/ $\mathrm{ml}$ ) appears to reduce the risk of thrombosis [15]. High plasma sEPCR (sEPCR $>130 \mathrm{ng} / \mathrm{ml}$ ) leads to dysfunction of EPCR-mediated coagulation [16].

The human EPCR gene is located on chromosome $20 q 11.2$ and is composed of 4 exons and 3 introns. Exon 1 encodes the 5' untranslated region (UTR) and the signal peptide, exons 2 and 3 encode most of the extracellular region of EPCR, and exon 4 encodes an additional 10 residues of the extracellular region of EPCR, the transmembrane domain, the cytoplasmic tail, and the 3' UTR $[15,17]$. In adults, EPCR is primarily located on the endothelial cells of large blood vessels, and exists in very low numbers or is absent from the microvascular endothelium of most tissues [18].

To date, more than 92 polymorphisms and 5 diseaserelated mutations have been observed on the human

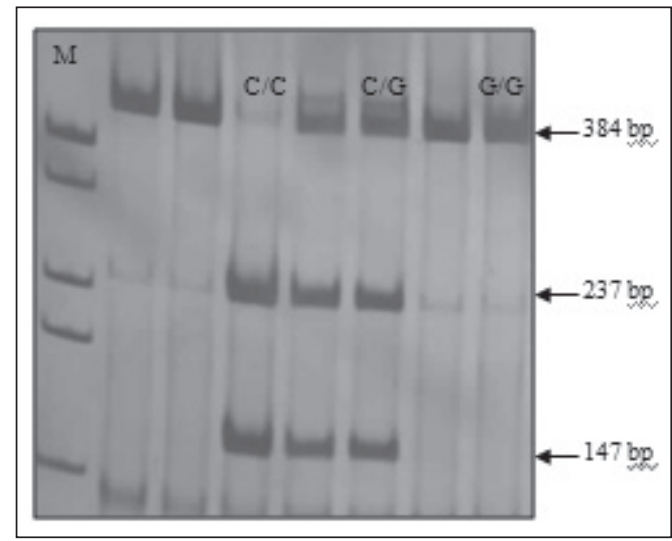

Figure 2: Restriction endonuclease analysis of C4678G polymorphism.
EPCR gene $[5,19,20]$. Among these polymorphisms and disease-related mutations a 23-bp duplication located between intron 2 and exon 3 (g.4189_4213dup TATCCACAGTTCCTCTGACCATC according to NT_011362.10) was reported to be associated with the risk of arterial and venous thrombosis $[21,22]$. A non-synonymous single nucleotide polymorphism (SNP) in exon 4, rs867186 (p.ser219gly; A4600G) (referred to as haplotype 3), is associated with elevated plasma sEPCR and causes thrombosis [23]. On the other hand, another polymorphism in the 3' UTR of the gene, rs9574 (C4678G) (referred to as haplotype A1), does not contribute to the risk of thrombosis [19,23-25]. This allele was also reported to be associated with a reduced risk of venous thrombosis [26]. As such, the present study aimed to investigate the effect of EPCR gene polymorphisms on the plasma sEPCR level in patients with venous thrombosis and healthy controls.

\section{Material and Methods}

The study included 111 patients and 73 controls. The patient group included 64 females (57.6\%) and 47 males (42.4\%), and the control group included 48 females (65.7\%) and 25 males (n34.3\%). Mean age in the control group was 28.5 years, versus 26.01 years in the patient group. None of the control group participants had a personal and a family history of venous thrombosis. All participants presented to Ankara University, School of Medicine, Department of Pediatric Molecular Genetics. All the participants provided written informed consent and the study was approved by the Ankara University School of Medicine Ethics Committee.

Plasma sEPCR was measured via enzyme-linked immunosorbent assay (ELISA) (Diagnostica Stago Asserachrom, Asnieres, France) [27]. DNA was isolated via proteinase K and phenol/chloroform extraction. All exons of the EPCR

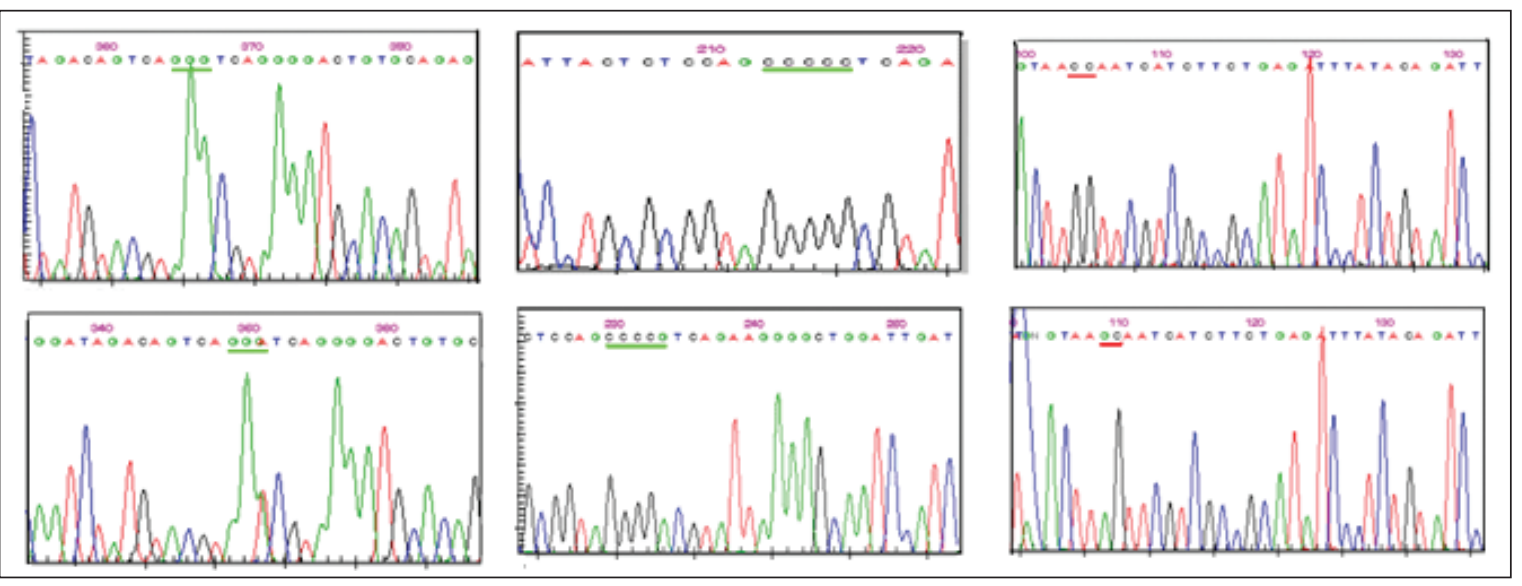

Figure 3: Sequencing results for C3998T(A), C4678G(B), and A4600G(C). 
gene were screened using polymerase chain reaction (PCR) and the following primers that were designed in our laboratory; 5'gccccctagtaggaaatga3' and 5'gagatgtgcccccgactc3' for exon 1 (293 bp), 5'caggcctccaaagacttcat3' and 5'cctactcacaggccaaggtc3' for exon 2 (264 bp), 5'gcaccctctctgcacagtc3' and 5'ccatccatttgtctggaacc 3 ' for exon 3 (384 bp), 5' taaacgggtccctttcctct3' and 5'ctcccctccctcaaatcttc3' for the $1^{\text {st }}$ region of exon 4 (384 bp), 5'caccagaaggtttggagtgac3' and 5'acgcctcaggtgattctgtc 3 ' for the $2^{\text {nd }}$ region of exon 4 (247 bp), and 5'ccatcctccaaagacagacag' and 5'ccagaaattttgcaaagtgga3' for the $3^{\text {rd }}$ region of exon 4 (278 bp).

Single strand conformation polymorphism (SSCP) was performed to determine if there was band pattern variation among the participants. SSCP was performed in 143 of the participants to detect the polymorphisms. Sequencing of the EPCR gene was performed when SSCP yielded a different band pattern (Beckman Coulter CEQ 8000, Beckman Coulter, USA). Direct sequencing of exon 4 was performed to detect A4600G mutation, whereas sequencing and RE analysis were used to detect C4678G mutation. All the participants were genotyped using 4678G to C substitution, which creates a Ddel restriction site (5'C/TNAG 3'). The samples were incubated using Ddel restriction enzyme (Fermentas UAB, Vilnius, Lithuania) at $37^{\circ} \mathrm{C}$ for $16 \mathrm{~h}$, and then the digestion products were electrophoresed on 3\% agarose gel (Sigma, USA).
Statistical analysis was performed using TADPOLE v.2.01 for Windows. The level of statistical significance was set at $\mathrm{P}<0.05$. The odds ratio (OR) and $95 \%$ confidence interval (CI) were calculated based on the logistic model. Allele frequencies were calculated via gene counting. In all these analyses the group with homozygous normal (4678 CC) served as the reference category to which risk was expressed.

\section{Results}

SSCP band pattern variation was noted in exons 3 and the first region of exon 4 (Figure 1). Three SNPs in exons 3 and 4 that have been previously described; (C3998T) rs2069952 [31-33], located in intron 2; (C4678G;A1 haplotype) rs9574 [31-33], located in 3'UTR and (A4600G; p.ser219gly A3 haplotype) rs867186 [31-33] located in exon 4; were observed in our control and patient groups. Restriction endonuclease analysis of C4678G polymorphism is shown in Figure 2, and sequencing results for C3998T, C4678G, and A4600G are shown in Figure 3. SSCP, on the other hand, showed that there wasn't any band pattern variation in exon 2 , or the $2^{\text {nd }}$ and $3^{\text {rd }}$ regions of exon 4. In the present study plasma sEPCR levels of 38-132 ng $\mu \mathrm{L}^{-1}$ were considered normal. sEPCR levels were significantly higher in participants (patients and controls) carrying the A3 allele. Among the participants that carried the Al allele, plasma sEPCR did not differ sig-

Table 1: Mean Plasma sEPCR Level in the Participants with the A3 Allele (SNP no: rs867186) and A1 Allele (SNP no: rs9574) [31,32,33]

\begin{tabular}{|c|c|c|c|c|c|c|}
\hline & & Controls & Patients & OR & $95 \%$ CI & $\mathbf{P}$ \\
\hline \multirow[t]{3}{*}{$\begin{array}{l}\text { A3 } \\
\text { Haplotype }\end{array}$} & 4600AA & $\begin{array}{c}60.17 \pm 28.9 \mathrm{ng} \\
\mu \mathrm{L}^{-1} \\
(\mathrm{n}=55)\end{array}$ & $\begin{array}{c}76.62 \pm 54.6 \mathrm{ng} \\
\mu \mathrm{L}^{-1} \\
(\mathrm{n}=75)\end{array}$ & 1 & - & \\
\hline & $4600 A G$ & $\begin{array}{c}160.17 \pm 60.3 \mathrm{ng} \\
\mu \mathrm{L}^{-1} \\
(\mathrm{n}=23)\end{array}$ & $\begin{array}{c}191.3 \pm 76.5 \mathrm{ng} \\
\mu \mathrm{L}^{-1} \\
(\mathrm{n}=33)\end{array}$ & 0.93 & $0.63-1.39$ & \\
\hline & $4600 G G$ & $\begin{array}{l}\text { 180ng } \mu \mathrm{L}^{-1} \\
\quad(\mathrm{n}=1)\end{array}$ & $\begin{array}{c}289 \pm 69.2 \mathrm{ng} \\
\mu \mathrm{L}^{-1}(\mathrm{n}=3)\end{array}$ & 1.26 & $0.85-1.85$ & 0.099 \\
\hline \multirow[t]{2}{*}{$\begin{array}{l}\text { Al } \\
\text { Haplotype }\end{array}$} & $4678 C C$ & $\begin{array}{c}51.72 \pm 35.1 \mathrm{ng} \\
\mu \mathrm{L}^{-1} \\
(\mathrm{n}=15)\end{array}$ & $\begin{array}{c}73.53 \pm 41.1 \mathrm{ng} \\
\mu \mathrm{L}^{-1} \\
(\mathrm{n}=13)\end{array}$ & 1 & - & \\
\hline & $4678 G G$ & $\begin{array}{c}90.71 \pm 57.1 \mathrm{ng} \\
\mu \mathrm{L}^{-1} \\
(\mathrm{n}=25)\end{array}$ & $\begin{array}{c}113.42 \pm 19.8 \mathrm{ng} \\
\mu \mathrm{L}^{-1} \\
(\mathrm{n}=19)\end{array}$ & 0.87 & $0.56-1.37$ & 0.041 \\
\hline
\end{tabular}


Table 2: Distribution of C3998T Polymorphism at Intron 2 of the EPCR gene

\begin{tabular}{|l|c|c|c|c|c|}
\hline C3998T & Controls (\%) & Patients (\%) & OR & $95 \%$ CI & P \\
\hline CC & $10(21.3 \%)$ & $32(31.7 \%)$ & 1 & - & \\
\hline CT & $19(40.4 \%)$ & $37(36.6 \%)$ & 0.6 & $0.24-1.49$ & 0.58 \\
\hline TT & $18(38.3 \%)$ & $32(31.7 \%)$ & 0.5 & $0.22-1.38$ & \\
\hline C & $39(41.5 \%)$ & $165(62 \%)$ & 1 & - & 0.0009 \\
\hline T & $55(58.5 \%)$ & $101(38 \%)$ & 0.43 & $0.26-0.70$ &
\end{tabular}

Table 3: Distribution of C4678G Polymorphism (Al Haplotype) at 3'UTR of the EPCR gene

\begin{tabular}{|l|c|c|c|c|c}
\hline C4678G & Control & Patients & OR & $95 \%$ CI & P \\
\hline CC & $13(17.8 \%)$ & $13(11.7 \%)$ & 1 & - & \\
\hline CG & $37(50.6 \%)$ & $79(71.2 \%)$ & 2.13 & $0.90-5.05$ & 0.018 \\
\hline GG & $23(31.6 \%)$ & $19(17.1 \%)$ & 0.82 & $0.31-2.20$ & \\
\hline C & $63(43.1 \%)$ & $105(47.2 \%)$ & 1 & - & 0.55 \\
\hline$G$ & $83(56.9 \%)$ & $117(52.8 \%)$ & 0.84 & $0.55-1.28$ & \\
\hline
\end{tabular}

Table 4: Distribution of A4600G Polymorphism (A3 Haplotype) at Exon 4 of the EPCR gene

\begin{tabular}{|l|c|c|c|c|c|}
\hline A4600G & Control & Patients & OR & $95 \%$ CI & P \\
\hline AA & $51(69.8 \%)$ & $75(67.6 \%)$ & 1 & - & \\
\hline AG & $21(28.8 \%)$ & $33(29.7 \%)$ & 1.06 & $0.55-2.05$ & 0.81 \\
\hline GG & $1(1.4 \%)$ & $3(2.7 \%)$ & 2.04 & $0.20-20.15$ & \\
\hline A & $123(84 \%)$ & $183(82.4 \%)$ & 1 & - & 0.65 \\
\hline
\end{tabular}

nificantly (Table 1). There wasn't a significant difference between controls and patients in the genotype frequency of C3998T substitution ( $\mathrm{P}=0.58, \mathrm{OR}=0.5, \mathrm{CI}=0.22$ 1.38), indicating that the $\mathrm{T}$ allele was not associated with the risk of venous thrombosis $(\mathrm{P}=0.0009, \mathrm{OR}=0.43, \mathrm{CI}=$ 0.26-0.70). C4678G substitution was not a risk for venous thrombosis $(\mathrm{P}=0.018, \mathrm{OR}=0.82, \mathrm{CI}=0.31-2.20)$; it might actually have offered protection against thrombosis. The 4600G allele was associated with a 2.04-fold increase in the risk of venous thrombosis for patient group, as compared to the control group, although the difference wasn't statistically significant $(\mathrm{P}=0.81, \mathrm{OR}=2.04, \mathrm{CI}=0.20$ 20.15) (Tables 2-4). The A3 haplotype was associated with both elevated plasma sEPCR and increased risk of venous thrombosis.

\section{Discussion}

Numerous variations in the EPCR gene have been reported. Any defect in the EPCR gene that leads to a reduction in receptor expression or impaired receptor function may stimulate the development of thrombosis. A 23-bp duplication of nucleotides between 4189 and 4213 at the genomic level, according to NT_011362.10 (a number of previous publications has referred this as position 4031) [28], results in an early stop codon and synthesis of a truncated protein that is not expressed on endothelial surfaces [21]. This duplication is associated with an increase in the risk of arterial and venous thrombosis $[21,22]$.

A polymorphism in exon 4 (A3 haplotype) encodes ser- 
ine instead of glycine at codon position 219 (NM006404.3); this occurs in the transmembrane region of EPCR [24]. This haplotype is reported to be responsible for $86.5 \%$ of the variation in plasma sEPCR levels [15]. Several studies have examined the correlation between p.S219G polymorphism and the risk of thrombosis. Saposnik et al. reported that the incidence of p.S219G polymorphism in patients with venous thrombosis is higher than that in healthy controls [23]. Ireland et al. observed that p.S219G homozygosity was associated with a 3-fold increase in the risk of coronary heart disease [29]; however, 2 other studies did not observe a similar correlation between p.S219G polymorphism and increased risk of venous thrombosis $[15,25]$. In the present study another polymorphism was identified—rs9574 (haplotype Al, C4678G)—that has been reported to be associated with high levels of circulating APC and a reduction in the risk of deep venous thrombosis (DVT) $[15,26]$. Saposnik et al. reported that the C4678G polymorphism had no effect on the plasma sEPCR level [23]. Furthermore, Saposnik et al. studied EPCR mRNA forms in eukaryote cells and compared their expression patterns based on cell genotype. They reported that there was a statistically significant higher quantity of mRNA that encoded a protein lacking the transmembrane domain in cells carrying A3 than in non-A3 carrying cells. They also reported that this EPCR protein was indeed synthesized and secreted, and that SEPCR was generated via ADAM17 cleavage [24].

Navarro et al. reported that mean age at initial onset of thrombosis was higher in non-carriers of the rs867186 (A4600G) allele ( $44 \pm 14$ years) than in carriers $(35 \pm 8$ years), and that the probability of not having thrombosis at age 40 years was lower in prothrombin $20210 \mathrm{~A}$ carriers with the EPCR A4600G allele. They also reported that the presence of the A4600G allele, plasma sEPCR >147 ng $\mathrm{mL}^{-1}$ and prothrombin $>129 \%$ all were associated with an increase in the risk of thrombosis. The risk of venous thromboembolism is influenced by the prothrombin level and the EPCR A3 haplotype, due to their effect on SEPCR levels [30]. Smoking, body mass index, ABO blood groups, levels of FII, FV, FVII, FIX, FX, FXI, FXII, and FXIII A and B subunits, fibrinogen, protein $S$, and antithrombin do not have any effect on the plasma sEPCR level [15].

The results of the present study confirm that there is a strong correlation between the A3 haplotype and elevated plasma sEPCR, as previously reported $[15,23,29]$. This allele also increased the risk of venous thrombosis 2-fold; however, there was a statistically significant difference between the patient and control groups, which might have been due to the small number of participants. The role of 3'UTR in RNA stability is known; as such, EPCR 3'UTR C4678G polymorphism (rs9574) might have an important thrombotic effect, but this hypothesis must be proven by large-scale studies. Moreover, C3998T polymorphism did not have a strong correlation with venous thrombosis in the present study. The present study's findings are in agreement with those previous published concerning sEPCR and EPCR gene haplotypes; however, additional research is needed in order to clarify the effects of EPCR gene mutations on venous thrombosis and inflammation.

\section{Conflict of Interest Statement}

The authors of this paper have no conflicts of interest, including specific financial interests, relationships, and/ or affiliations relevant to the subject matter or materials included.

\section{Acknowledgment}

This study was supported by the Turkish Society of Hematology.

\section{References}

1. Esmon CT: Inflammation and the activated protein $\mathrm{C}$ anticoagulant pathway. Semin Thromb Hemost 2006; 32 (Suppl 1): 49-60

2. Dahlback B: Blood coagulation. Lancet 2000; 355: 1627-1632

3. Taylor FB Jr, Peer GT, Lockhart MS, Ferrell G, Esmon CT: Endothelial cell protein $C$ receptor plays an important role in protein C activation in vivo. Blood 2001; 97: 1685-1688

4. Fukudome K, Esmon CT: Identification, cloning and regulation of a novel endothelial cell protein C/activated protein C receptor. J Biol Chem 1994; 269: 26486-26491

5. Esmon CT: The endothelial cell protein $C$ receptor. Thromb Haemost 2000; 83: 639-643

6. Stearns-Kurosawa DJ, Kurosawa S, Mollica JS, Ferrell GL, Esmon CT: The endothelial cell protein $C$ receptor augments protein $\mathrm{C}$ activation by the thrombin-thrombomodulin complex. Proc Natl Acad Sci USA 1996; 93: 10212-10216

7. Zecchina G, Bosio S, Brusa E, Rege-Cambrin G, Camaschella C: EPCR 23 bp insertion in a patient with severe progressive arterial disease: A dominant loss of function mutant in conditions of increased APC request? Br J Haematol 2002; 119 (3): 881-882

8. Esmon CT, Ding W, Yasuhiro K, Gu JM, Ferrell G, Regan LM, Stearns-Kurosawa DJ, Kurosawa S, Mather T, Laszik Z, Esmon NL: The protein $C$ pathway: New insights. Thromb Haemost 1997; 78 (1): 70-74 
9. Kurosawa S, Stearns-Kurosawa DJ, Hidari N, Esmon CT: Identification of functional endothelial protein $\mathrm{C}$ receptor in human plasma. J Clin Invest 1997; 100: 411-418

10. Griffin JH, Evatt B, Wideman C, Fernández JA: Anticoagulant protein $C$ pathway defective in majority of thrombophilic patients. Blood 1993; 82: 1989-1993

11. Xu J, Qu D, Esmon NL, Esmon CT: Metalloproteolytic release of endothelial cell protein $\mathrm{C}$ receptor. J Biol Chem 1999; 275: 6038-6044

12. Liaw PC, Neuenschwander PF, Smirnov MD, Esmon CT: Mechanisms by which soluble endothelial cell protein C receptor modulates protein $C$ and activated protein $C$ function. J Biol Chem 2000; 275: 5447-5452

13. Kurosawa S, Stearns-Kurosawa DJ, Carson CW, D'Angelo A, Della Valle P, Esmon CT: Plasma levels of endothelial cell protein $C$ receptor are elevated in patients with sepsis and systemic lupus erythematosus: Lack of correlation with thrombomodulin suggests involvement of different pathological processes. Blood 1998; 91: 725-727

14. Dahlback B: The protein C anticoagulant system: Inherited defects as basis for venous thrombosis. Thromb Res 1995; 77: $1-43$

15. Uitte de Willige S, Van Marion V, Rosendaal FR, Vos HL, de Visser MC, Bertina RM: Haplotypes of the EPCR gene, plasma sEPCR levels and the risk of deep venous thrombosis. J Thromb Haemost 2004; 2: 1305-1310

16. Ulu A, Gunal D, Tiras S, Egin Y, Deda G, Akar N: EPCR gene A3 haplotype and elevated soluble endothelial protein $C$ receptor (sEPCR) levels in Turkish pediatric stroke patients. Thromb Res 2007; 120 (1): 47-52

17. Simmonds RE, Lane DA: Structural and functional implications of the intron/exon organization of the human endothelial cell protein C/activated protein C receptor (EPCR) gene: Comparisons with the structure of $\mathrm{CDl}$ / major histocompatibility complex alphal and alpha2 domains. Blood 1999; 94: 632-641

18. Laszik Z, Mitro A, Taylor FB Jr, Ferrell G, Esmon CT: Human protein $C$ receptor is present primarily on endothelium of large blood vessels: Implications for the control of the protein C pathway. Circulation 1997; 96: 3633-3640

19. Medina P, Navarro S, Estellés A, Vayá A, Bertina RM, España F: Influence of the A4600G and C4678G polymorphisms in the endothelial protein $C$ receptor (EPCR) gene on the risk of venous thromboembolism in carriers of factor $\mathrm{V}$ Leiden. Thromb Haemost 2005; 94 (2): 389-394

20. Franchi F, Biguzzi E, Cetin I, Facchetti F, Radaelli T, Bozzo M, Pardi G, Faioni EM: Mutations in the thrombomodulin and endothelial protein $C$ receptor genes in women with late fetal loss. Br J Haematol 2001; 114 (3): 641-646
21. Akar N, Gökdemir R, Ozel D, Akar E: Endothelial cell protein $C$ receptor (EPCR) gene exon III, 23 bp insertion mutation in the Turkish pediatric thrombotic patients. Thromb Haemost 2002; 88 (6): 1068-1069

22. Zecchina G, Bosio S, Brusa E, Rege-Cambrin G, Camaschella C: EPCR 23 bp insertion in a patient with severe progressive arterial disease: A dominant loss of function mutant in conditions of increased APC request? Br J Haematol 2002; 119 (3): 881-882

23. Saposnik B, Reny JL, Gaussem P, Emmerich J, Aiach M, Gandrille S: A haplotype of the EPCR gene is associated with increased plasma levels of SEPCR and is a candidate risk factor for thrombosis. Blood 2003; 103: 1311-1318

24. Saposnik B, Lesteven E, Lokajczyk A, Esmon CT, Aiach M, Gandrille S: Alternative mRNA is favored by the A3 haplotype of the EPCR gene PROCR and generates a novel soluble form of EPCR in plasma. Blood 2008; 111 (7): 3442-3451

25. Medina P, Navarro S, Estellés A, Vayá A, Woodhams B, Mira Y, Villa P, Migaud-Fressart M, Ferrando F, Aznar J, Bertina RM, España F: Contribution of polymorphisms in the endothelial protein $C$ receptor gene to soluble endothelial protein $C$ receptor and circulating activated protein $C$ levels, and thrombotic risks. Thromb Haemost 2004; 91: 905-911

26. Espana F, Medina P, Mira Y, Estelles A, Vaya A, Villa P, Royo M, Aznar J, Bertina RM: A new polymorphism in the 3'UTR region of the endothelial protein $C$ receptor associated with increased levels of circulating activated proten $C$ and decreased risk of venous thrombosis. Thromb Haemost 2001; 1: Abstract OC885

27. Yürürer D, Teber S, Deda G, Egin Y, and Akar N: The Relation Between Cytokines, Soluble Endothelial Protein C Receptor, and Factor VIII Levels in Turkish Pediatric Stroke Patients. Clin Appl Thromb Hemost 2009; 15: 545-551

28. Kendirli T, Ciftçi E, Ince E, Yurdakul E, Kansu A, Akar $\mathrm{N}$ : Homozygous 23-bp insertion of endothelial protein c receptor gene in a child with fatal sepsis. Pediatr Hematol Oncol 2007; 24 (3): 199-204

29. Ireland H, Konstantoulas CJ, Cooper JA, Hawe E, Humphries SE, Mather H, Goodall AH, Hogwood J, Juhan-Vague I, Yudkin JS, di Minno G, Margaglione M, Hamsten A, Miller GJ, Bauer KA, Kim YT, Stearns-Kurosawa DJ, Kurosawa S: EPCR Ser219Gly: Elevated sEPCR, prothrombin F1_2, risk for coronary heart disease, and increased sEPCR shedding in vitro. Atherosclerosis 2005; 183: 283-292

30. Navarro S, Medina P, Mira Y, Estellés A, Villa P, Ferrando F, Vayá A, Bertina RM, España F: Haplotypes of the EPCR gene, prothrombin levels and the risk of venous thrombosis in carriers of the prothrombin G20210A mutation. Haematologica 2008; 93 (6): 885-891 
31. The National Center for Biotechnology Information. Available from: http://www.ncbi.nlm.nih.gov/sites/entrez?d b=snp\&cmd=search\&term $=$ rs2069952

32. The National Center for Biotechnology Information. Available from: http://www.ncbi.nlm.nih.gov/sites/entrez?d b=snp\&cmd=search\&term $=$ rs867186
33. The National Center for Biotechnology Information. Available from: http://www.ncbi.nlm.nih.gov/sites/ entrez ?db=snp\& $\mathrm{cmd}=$ search\&term $=$ rs9574 